\title{
新幹線用台車の強度 (II)*
}

\section{4 車 輪の強度}

車輪に働く負荷は $\mathbf{3}$ で述べたととからわかっている ので, 静的に応力測定を行ない, 過去の経験と考え合 わせて材質，寸法などを定めた。

設計図は図400ようで，円板ブレーキをつけるため
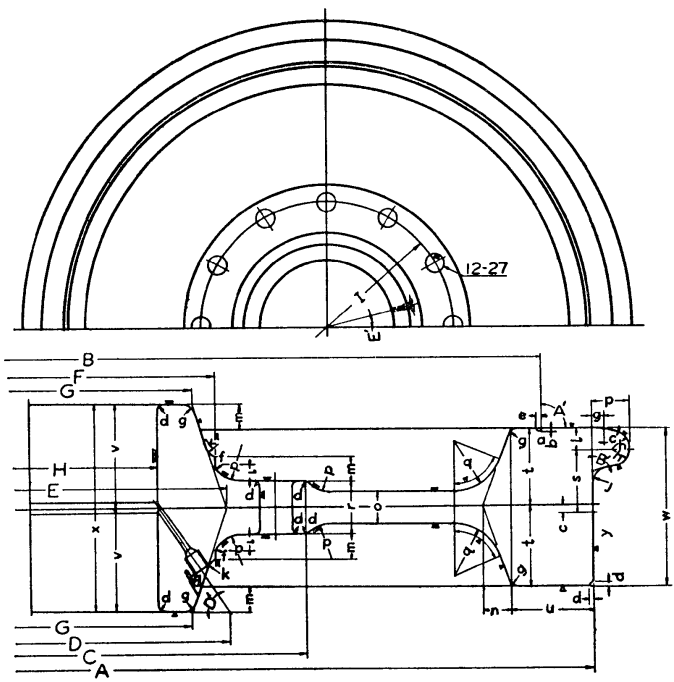

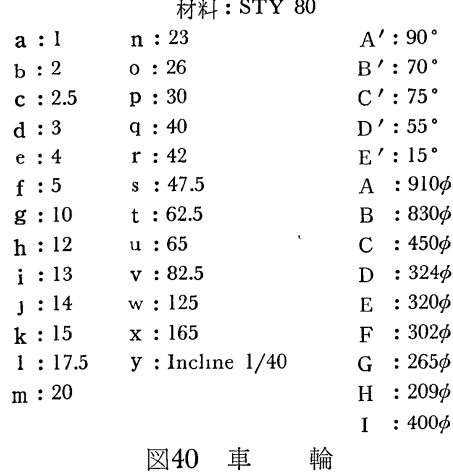

の穴があいていて，また，そのために円板部は直線的 に結ばれている。

住友金属では車輪の中央に仮軸を圧入し，仮軸の上 下面を固定し，フランジの所に横圧をかけて静応力を 測定した，そのときのひずみ計貼布位置を図41に，そ

\footnotetext{
* 原稿受理 昭和41年 8 月 19 日

** 正 会員 鉄道技術研究所 国分寺市光町

*1 中村宏，材料， 16，71 82 (1967) 参照
}

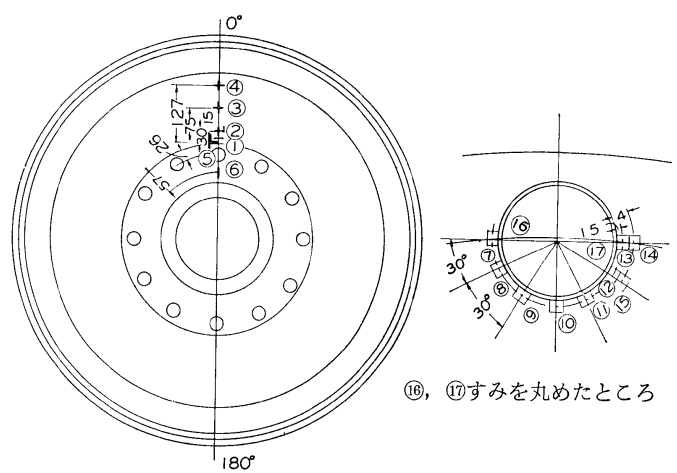

図41 応力测定の位置

表IV車輸リムに横圧を加えたときに生ずる応力

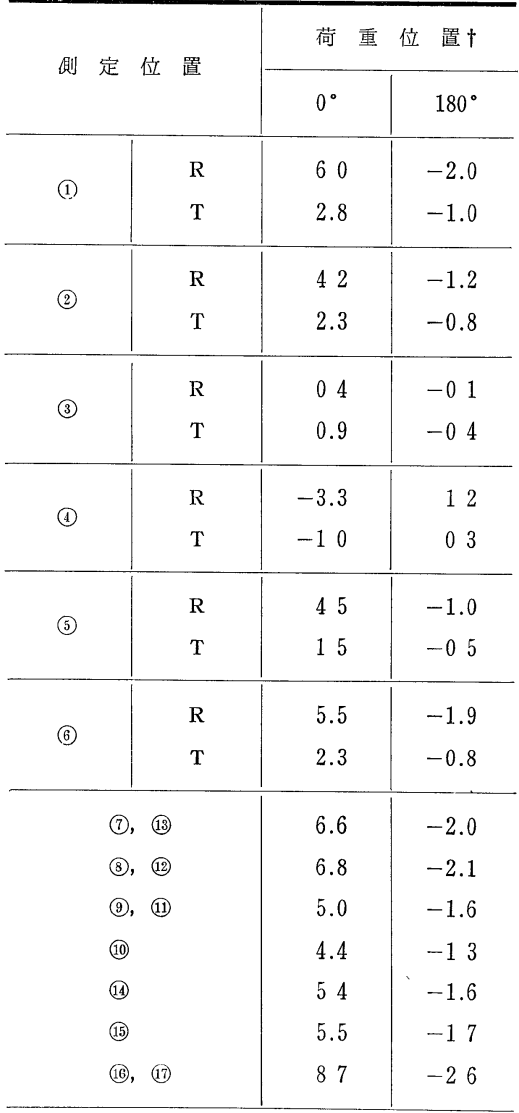

$\dagger 0^{\circ}$; 則定点を含む半径方向汇荷重を加えたとき $180^{\circ} ;$ 上の反対の半径方向に荷重を加えたとき 


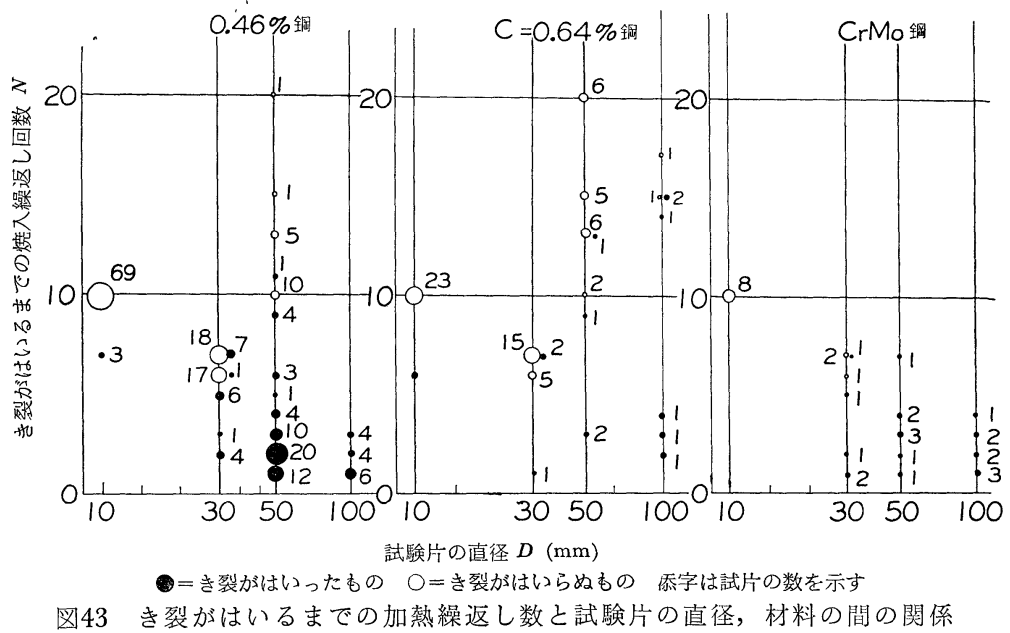

の結果は表IVに示す.

最も大きい応力はNo. 8 と No. 120 位置に発生し， 橫圧 $5 \mathrm{t}$ 亿対して， $6.8 \mathrm{~kg} / \mathrm{mm}^{2}$ でている。測定結果 で Qの最大は $7.5 \mathrm{t}$ ぐらいであるから(図23)，乙の 板車輪の最大応力は約 $10 \mathrm{~kg} / \mathrm{mm}^{2}$ とみなしうる.

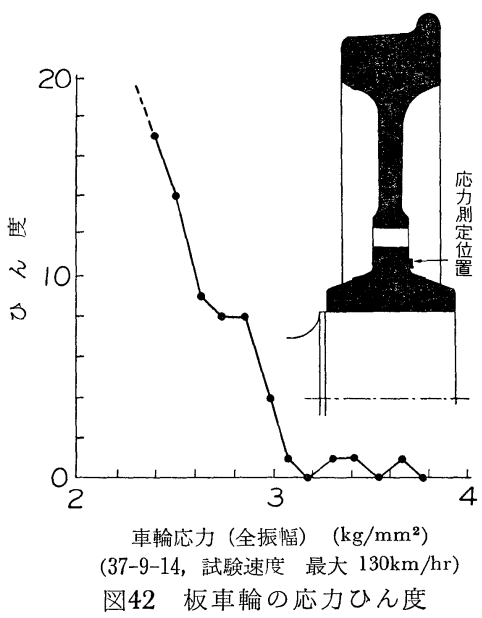

図42は最高速度 $130 \mathrm{~km} / \mathrm{hr}$ のときの資料であるが， 図のひずみ計貼布位置での走行中の応力振幅の最大は $4 \mathrm{~kg} / \mathrm{mm}^{2}$ であるてとを示す.

したがって，ての車輪板部の疲労限度と比べて充分 余裕があると考えてさしつかえなからう。

実物について上記静荷重試験とほぼ同じ状態で疲学 試験が行なわれた。

図41，表IVでの No. 7 またはNo.13の位置の応力で 疲労限度を表わすと STY 80 に対して (2.5〜34.0) $=18.25 \pm 15.75 \mathrm{~kg} / \mathrm{mm}^{2}$ となり, 上記の横圧による 応力と比べて安全である.

その上車輪の場合は踏面が摩耗して取り変え限度に 達すると，取りはずすので，有限の寿命を要求されそ の点でも車軸より楽である.
材質の選定に際しては，フラットを起てしたときの き裂に対する感受性をみるために，円壔に高周波焼入 れを繰り返し，き裂が発生するまでの回数を調べた。 図43がその結果で， $0.64 \% \mathrm{C}$ 鋼が最も成績がよいとと がわかった。

別にSTY 80 を用いリム・クエンチする方法, $\mathrm{*}$ - $\mathrm{Mo}$ 鋼の踏面高周波焼入れの方法，STY 80 を断続的に踏 面を高周波焼入れする方法についても，実物の試料を 作って残留応力測定や材質試験を行ない，また GrMo 鋼と STY 80 の比較はわずかの数ではあるが試験用 電車につけて調査した。

以上の努力はしたが，結局は旧てだまなどで用いて いる STY 80 をリム・クエンチする方法が採用され た.

走ったあとの踏面の強度を調べるために，使用後の 車輪について残留応力を調べた. その結果を図44亿示 す. 踏面の表面は走行することにより圧延され, 圧縮

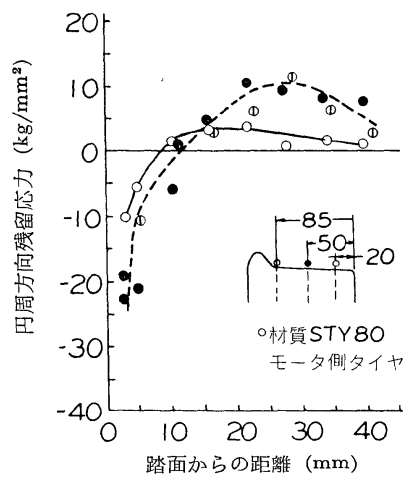

図44 走行後の車輪踏面切線方向残留応力測定結果

*2 STY 80 の成分範囲のむの

*3 車輪全体を加熱し, 踏面部のみ水を加けて焼入れする方法, も どしは (500〜 530) ${ }^{\circ} \mathrm{C}$ かたさは $H_{S} 44 〜 50$ にした

*4 中村宏, 材料, 16，83 (1967)参照 
残留応力になっている.

また，フラットが生じた後の残留応力を調べで, 保安上の参考とした.

てれまでの使用の結果では, 強度上の問題はでてい ないが，台車と軌道の構造と，高速であるととからく る原因のためであろう, 踏面のフランジつけ根の摩耗 が多く, 良好にして安全な走行状態を保つために, 車 㫻削正の費用がかさんでいる，対策をたてるととが望 まれているが, 摩耗に強くて，かつ強度にも絶対にだ いじょうぶである車輪を作るととはそうたやすいてと ではない。

\section{5 たわみ板ばね}

たわみ板ばねは軸箱を支持するためのもので図 4 の ような原理になっている。だ行動を防止するために前 後, 左右の剛性が $\mathbf{3 . 8}$ で述べたようになっていて, 上 下の剛性は軸ばね（コイルばね）でとり，たわみ板ば ね自身の上下の剛性はほとんど無視してもさしつかえ ないように設計されている。したがって，たわみ板ば ねの応力は軸ばねの変位に支配される。

応力測定を行なったが，ひずみ計貼布位置は図45に 示すようで, 各测定点の応力の比率は図46のようであ る. 自由端に近い台車わく側の応力（No. 4 点）は小 さく，固定端である軸箱側の応力のほうが大きい，た

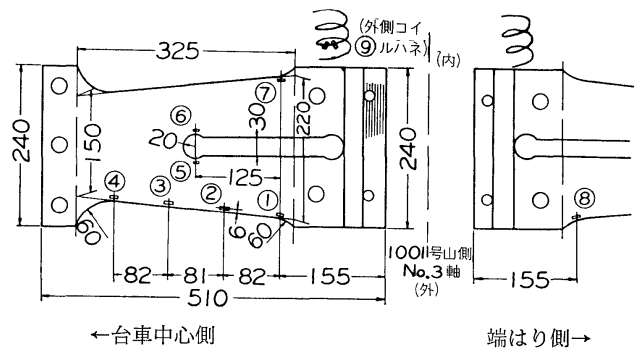

図45 I S 式軸箱支持装置たわみ板の応力測定点

$39-1-15$

$210 \mathrm{~km} / \mathrm{hr} 104 \nu, 105 \nu$ OSC No. 6

$55 \sim 61 \mathrm{~km}$ 区間上り線

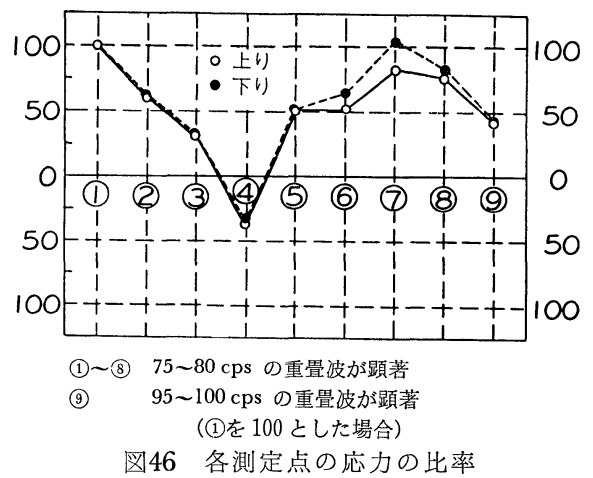

*5 ミンテン式の場合は両端がほほ固定端に近くなるのて, 同し変 位に対しては応力がほほ 2 倍近くなる。ＩＳ式を採用した理由 は，たわみ板は极の強宽むその一つてある
わみ板の応力は速度とともに増加するととは図47をみ るとわかる。

この部材の応力は形が複雑であるので, ひん度の取 り方には検討すべきととも多いが，電気機関車のたわ み板ばねの折損原因を究明したときの手法を採用した。

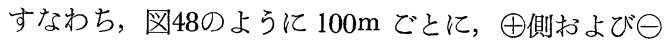
側の最大応力を取り，てれのひん度を求めた，東京一

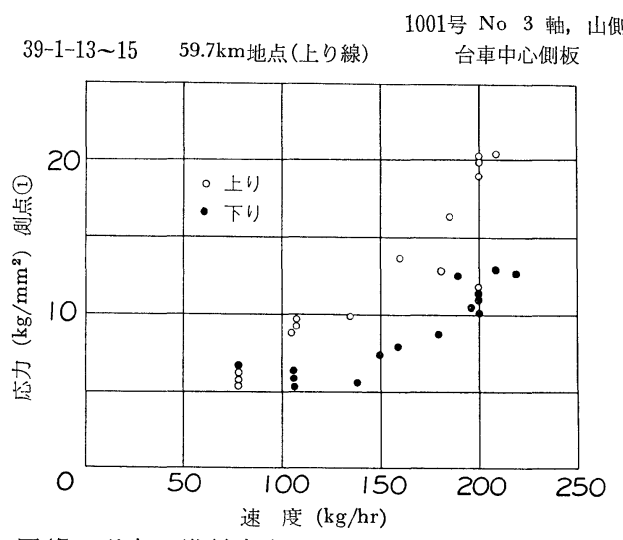

図47列車の進行方向によるたわみ板応力の比較

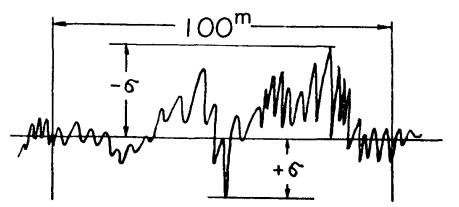

四48 たわみ板ばね応力ひん度の読み力

$398.15 \sim 39.8 .18$

S3編成 No 3 軸山側台車中心方向板はね ( $100 \mathrm{~m}$ 区間ことの片振幅最大値)

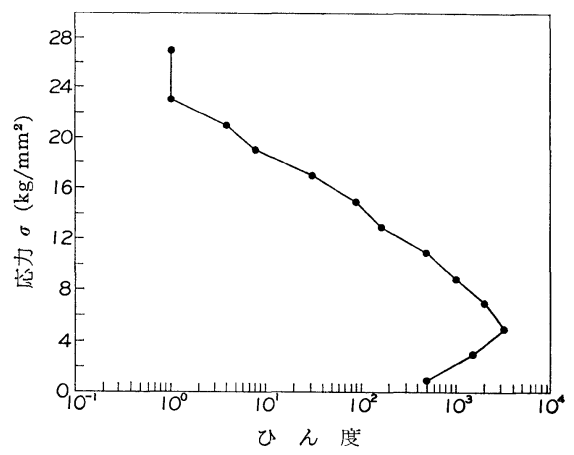

図49 東京一新大阪間たわみ板の応力ひん度

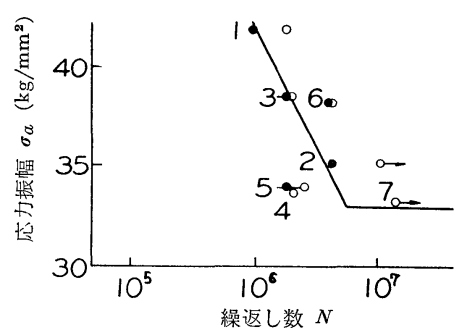

図50たわみ板の疲労試験結果 
軸はね軟，軸はねタンパあり

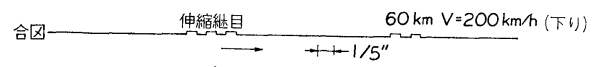

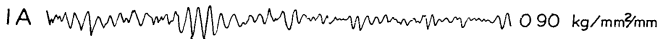

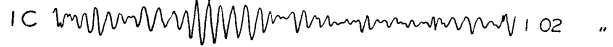

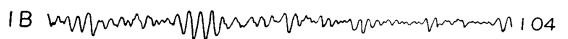

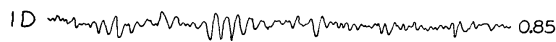

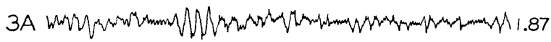

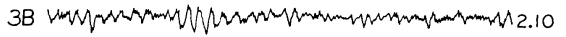

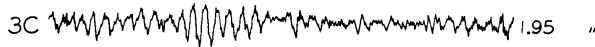

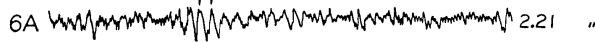

軸は教，軸はねダンパなし

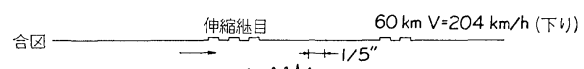

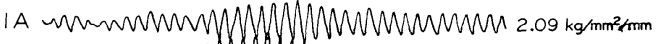

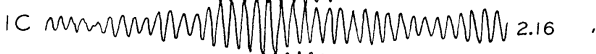

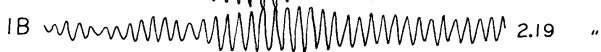

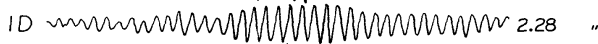

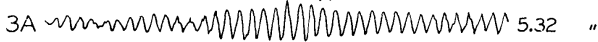
3B mur

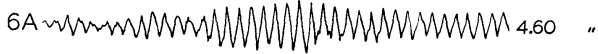

図51軸ばね応力のオシロ記録例

上り
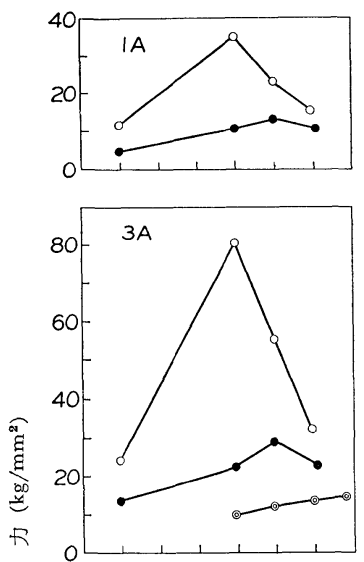

㘪

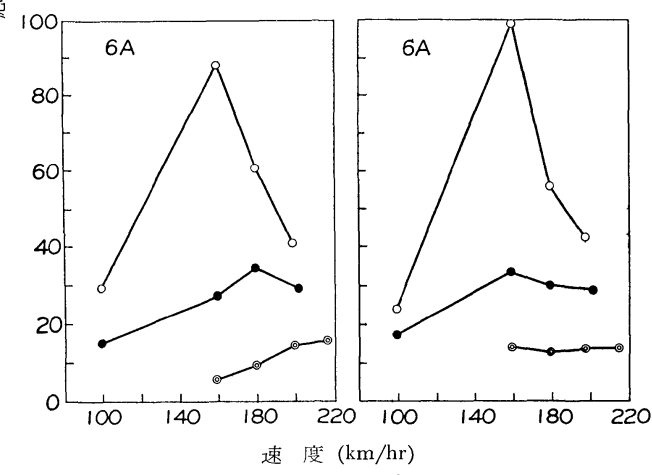

応力は全振幅の值 ○ダンパなし ダンパ付 ○エリコ

図52 軸ばね応力 $(60.7 \mathrm{~km}$ 地点に抢ける $1 \mathrm{~A}, 3 \mathrm{~A}, 6$ $\mathrm{A} の$ 応力の比較)
新大阪間の忘力ひん度の測定例を図49に示す。

板ばねについては以前にも疲労試験を行ない，また 今回のたわみ板ばねについても実物の疲労試験を行な っで, 平面曲げ瘦労限度は土 $(30 \sim 45) \mathrm{kg} / \mathrm{mm}^{2}$ (罚50 参照）で，図49と比べて充分安全と考えた。

なお，室内実験の疲労限度の半分を疲労限度にみて， 寿命計算をしても 200〜300万 $\mathrm{km}$ の寿命があるととが 計算ではでている。

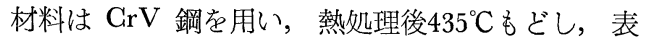

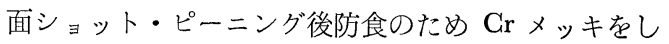
てある.

\section{6 軸ばね部の構造}

軸ばねにはコイルばねを用いたが，乙れに平行に才 イルダンパを入れるるととの要, 不要が討論された. 走 行試験結果の一例は図51で，乙れらをまとめたものの 一部は図52で, オイルダンパをはずすと, 速度が 160 $\mathrm{km} / \mathrm{hr}$ をてえたとき，共振でばねの応力が非常に大 きくなり，ばねの強度上からも乗り心地の点からも才 イルダンパを省略するととができないととが判明した。 したがって, 量産設計ではオイルダンパをつけるとと にした.

軸ばねの応力は図49のたわみ板ばねの応力から推定 でき，全区間の最大值は $\pm 17 \mathrm{~kg} / \mathrm{mm}^{2}$ である，Sup. 9 を焼入燒もどししショット・ピーニングしてある.

\section{7 台車 わく}

台車わくは輪軸，ばね等を支持するもので，構造は
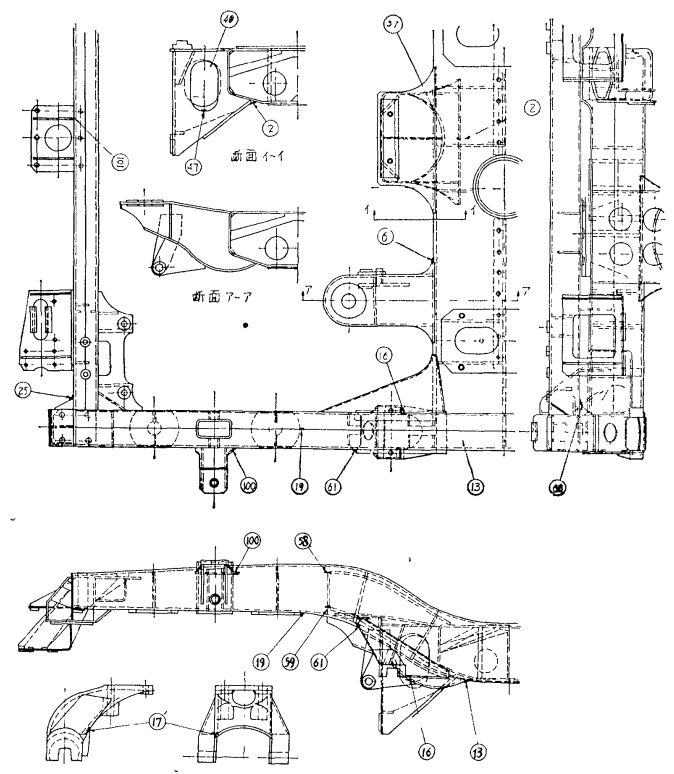

取付金（端はり側）

新幹線量産試作車台車応力則定点

39-1-13 15 上り線 1001号 No 2 台車

図53 (a) 新幹線量産試作車台車応力測定点

*6 コイルは权内側の応力 


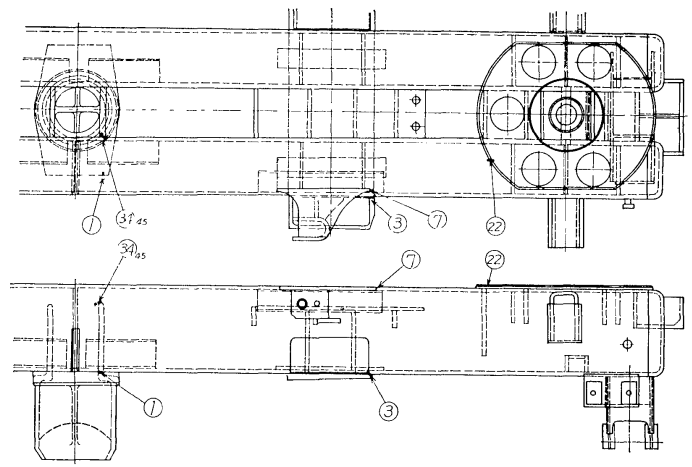

表 V (a) 荷重試験の種類と荷重

まくらはり応力測定点

39-3-8 11 下り線(上り線) 1011号 No. 2 台車

図53 (b) まくらはり応力測定点

表 V (b) 量産車静荷重試験応力 (単位 $\mathrm{kg} / \mathrm{mm}^{2}$ ) (汽車会社の側定による)

\begin{tabular}{|c|c|c|c|c|c|c|c|c|}
\hline & \multirow{2}{*}{ 測点 } & \multicolumn{2}{|c|}{ 垂 直 荷 重 } & \multirow{2}{*}{$\begin{array}{l}\text { 㸚しり } \\
\text { 荷 重 }\end{array}$} & \multicolumn{2}{|c|}{ 軸受支持部 } & \multirow{2}{*}{$\begin{array}{c}\text { 主電動機受 } \\
\text { 荷 重 }\end{array}$} & \multirow{2}{*}{$\begin{array}{l}\text { 歯車箱つり受 } \\
\text { 何 重 }\end{array}$} \\
\hline & & $20.5 \mathrm{t}$ & $\begin{array}{l}02 \mathrm{~g}(\text { まらはり) } \\
\text { または３３（台車 } \\
\text { わく）相当分 }\end{array}$ & & 左右荷重 & 前後荷重 & & \\
\hline \multirow{5}{*}{$\begin{array}{l}\text { ま } \\
\text { く } \\
\text { ら } \\
\text { は } \\
\text { り }\end{array}$} & 1 & -19.3 & -1.86 & & & $-2.3+1.2$ & & \multirow{5}{*}{$r$} \\
\hline & 3 & -22.0 & -4.40 & & & $+3.5-2.8$ & & \\
\hline & 7 & +10.6 & +2.12 & & & $-3.9+2.9$ & & \\
\hline & 22 & +11.1 & +2.22 & & & $-2.4+2.1$ & & \\
\hline & 34 & +7.47 & +1.49 & & & $-4.0+2.3$ & & \\
\hline \multirow{5}{*}{ 台 } & 13 & -9.14 & -2.74 & -150 & +0.10 & +0.21 & -252 & -40 \\
\hline & 37 & +2.21 & +0.66 & & 0 & 0 & -326 & -0.63 \\
\hline & 40 & -140 & -042 & -0.42 & +021 & 0 & +8.83 & -0.53 \\
\hline & 68 & +3.1 & +0.93 & -3.99 & +7.77 & -2.52 & +0.63 & +032 \\
\hline & 101 & - & - & - & - & - & - & - \\
\hline
\end{tabular}

各応力は補強前の側定值を示した, 補強後は多少减少している

図53のようである。乙れまでにも多くの応力測定を行 ない，賃人り防止策をたててきた経験を生かして設計 されたもので, 静荷重による応力を平均応力とし, 走 行中の応力を振幅にとって図54の限界内にはいること で強度上の安全不安全を決めた。

材料は SS41P を用い高抗張力鋼は用いなかった。 高抗張力鋼を用いなかつた理由は，(1)台車わくはその 構造上溶接をしがたい所があること，(2)溶接ビードを 仕上げると疲学強度が高いが，ビードがあると疲労強 度は SS41 とあまり変わりがなく，てれれまでの高抗張 力鋼の実績もあまりよくないとと（3)設計を巧みにす れば，SS41Pで充分強度がもつような設計ができるて と.この 3 点からである.

静荷重試験 (表 $V$ 参照) で応力の大きい所は補強し, また走行試験をしないと判明しない所は走行試験を行 なって応力の大きくないてとを確かめるまで改良を加 えた. 以下，簡単に説明を加えよう.

図53の図面での測定点は動的応力を測定した点であ
るが，測定結果は表Vのとおりで，No.40，68，101， （特にNo. 101）がやや大きい応力を示している.

No. 101 はブレーキ増圧シリンダが台車わく端はり につり下がっているつけ根で， 50〜60 cps の共振波 形を呈していて, 静荷重試験では応力のでなかった所 である、溶接部であるから注意する必要がある。

なお，応力の大きい所は溶接したあとビードの端の 応才集中部は研摩して, 瘦労破壊のおそれがないよう

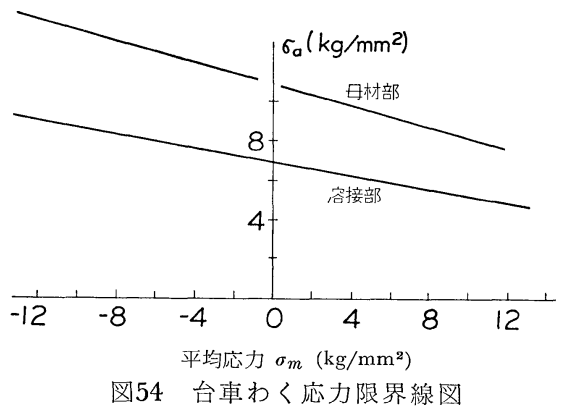




中 村 宏

表 VI 新幹線量産車台車わく，ゆれまくらの動的応力

区間最大值 (全振幅, 単位 $\mathrm{kg} / \mathrm{mm}^{2}$ )

39-3-8 -11 55 64 km 1011号 No. 2 台車

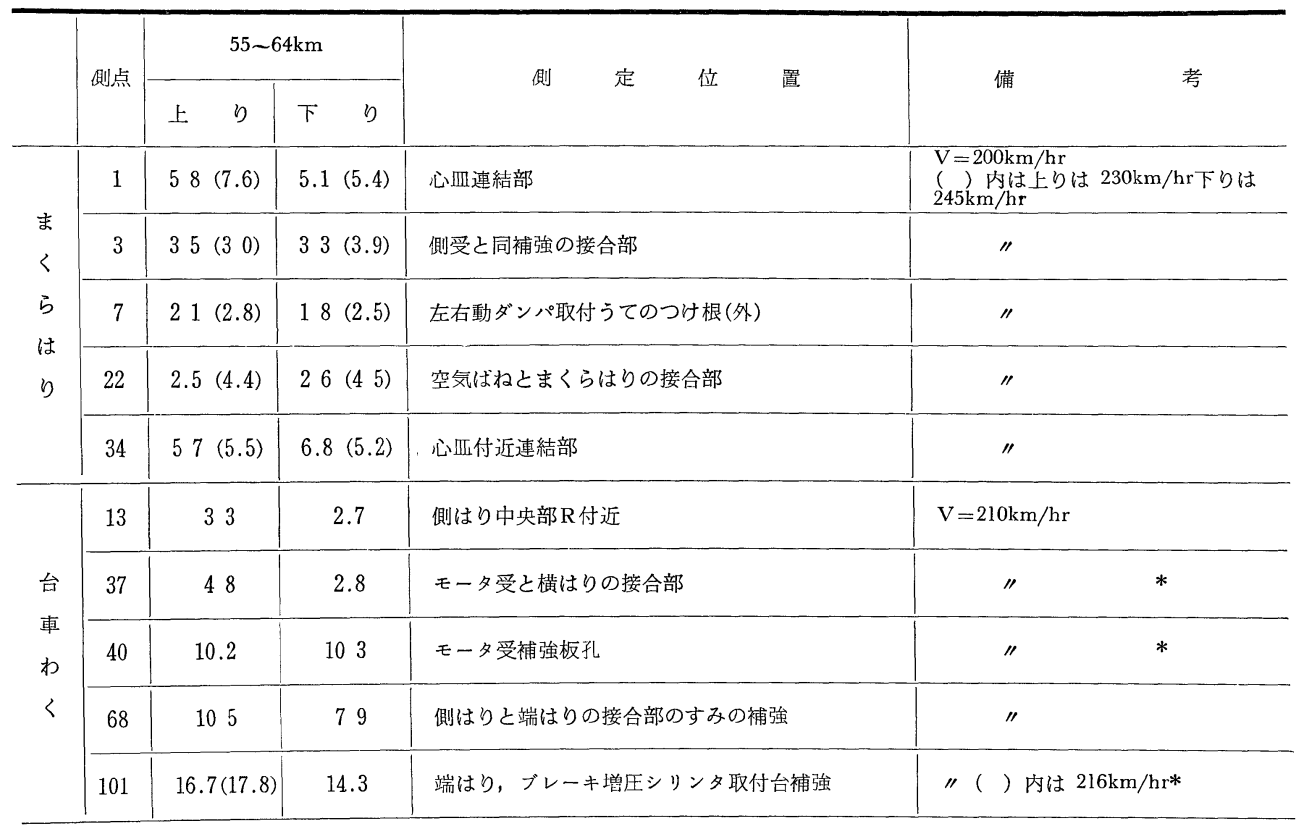

* 50 60cps の振動波形を顕著に示すすの
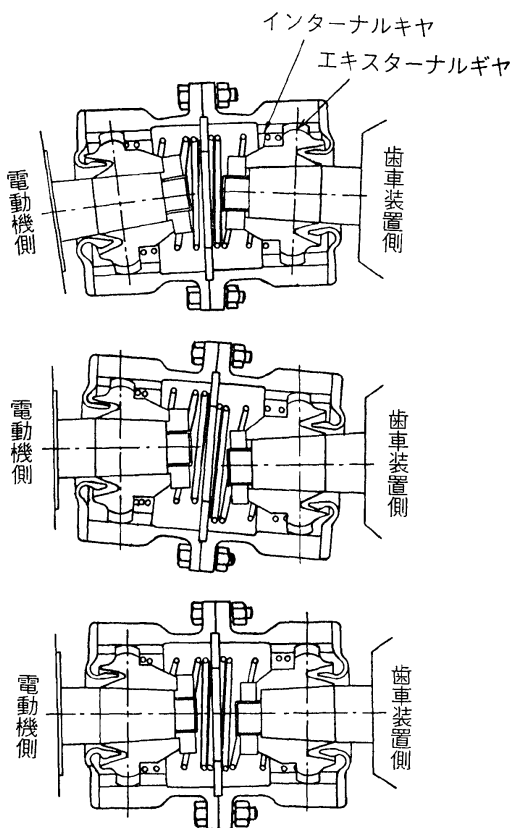

図55可とう歯車継手の構造

そした.

使用の結果では，No. 101 の近傍の溶接ビードの不 良の所に数件き裂がはいったが，補強後問題はなくな った。 なお，この場所の全線応力測定結果の最大応力 は $\pm 7 \mathrm{~kg} / \mathrm{mm}^{2}$ であった。

\section{8 歯事, 駆動装置}

大歯車，小歯車や電動機と霜車を結んでいる W-N 継手 (図55) も過去の実績をもとにして設計，製作され た。

材質，熱処理法の大要は表VIのとおりである，歯車 に働くトルクから応力を推定したととろ車輪がフラッ トを起こしたときでも最大 $17 \mathrm{~kg} / \mathrm{mm}^{2}$ 程度で，普通 表 VII 崡車材料熱処理条件

$\begin{array}{lll}\text { 材料 } & \text { 熱処理法 } & \text { 硬度 } \\ \mathrm{S} 40 \mathrm{C} & \text { 高周佊烧入焼むとし } & \text { 歯先65 75 } \\ & & \text { 歯底60以上 }\end{array}$

小歯車 SNCM23，浸炭焼入焼もどし $H_{S} 75 \sim 85$

$\alpha=20^{\circ}, M=8, Z=63 / 29$

$x_{1}=+0.6000, x_{2}=-0.1653$

$\beta_{1}=20^{\circ}$ 左 $\beta_{2}=20^{\circ}$ 右

大歯車 円周力 $4000 \mathrm{~kg}$ のとき 小歯車応力 $150 \mathrm{~kg} / \mathrm{mm}^{2}$ 大歯車応力 16.5 "

W.N. 継手 $\quad \alpha=20^{\circ}, M=4 / 3, Z=50$

\begin{tabular}{|c|c|c|}
\hline & 外歯㐘車 & 内齒菌車 \\
\hline$A$ 社 & $\begin{array}{l}\mathrm{S} 45 \mathrm{C} \text { 高周波焼入れ } \\
\text { 燒むどし } H_{S} 75 \text { 以上 }\end{array}$ & $\begin{array}{l}\text { SNCM } 23 \\
\text { 唚炭燒入焼むどし } \\
H_{S} 70 \text { 以上目標 } 75\end{array}$ \\
\hline B社 & $\begin{array}{c}\text { SCM5 燒入焼もとし } \\
H_{S} \text { 75以上 } \\
\text { S45C 高周波焼入れ } \\
\text { 焼もどし }\end{array}$ & $\begin{array}{l}\text { SCM } 4 \\
\text { 火炎焼入焼もどし } \\
\text { SNCM } 23 \\
\text { 浸炭焼入焼もどし }\end{array}$ \\
\hline
\end{tabular}


は $4 \mathrm{~kg} / \mathrm{mm}^{2}$ ぐらいであり 従来のものと比べて強度 上問題はないと判断された。

なお，歯車については国鉄では以前から仕様書を制 定し, 歯底の残留応力や粜底部から切り出した試験片 や実体の疲労試験の資料を蓄積し，顕微鏡組織，硬度 分布の資料を整理していたので，乙れらの資料をも参 考にして，最終的な設計の仕様を決めた。

高周波焼入歯車の硬化深度はマク口組織で $2 \mathrm{~mm}$ 以 上と仕様書で定められている。

\section{9 そ 他}

以上のほかに，軸受，ボルスタアンカ，ディスク・ ブレーキ，側受などがあり，それぞれに記述しなけれ ばならないこともあるが，紙数の都合でここでは割愛 する。

\section{0 結言}

以上，やや車軸の強度にかたよりすぎたが，新幹線 用台車の強度について現在までの経過を略述した。

いずれの部品にしても，応力は試験片で期待される 值に比べてかなり低く押さえている.

てのように安全率を大きくとった理由としては過去 の経験を加味しているのではあるが，その中には純粋 に学問的にわかっていないものと，いわゆる“ばらつ き”と称している漠然とした材料，熱処理，機械加工， 管理面などに対する不安をカバーしている面がある.

実際の品物に触れ，また，それがたいせつな人命に 関係するものであるだけに，最も判断に困るのは後者 の“ばらつき”と称するものである.

これを少なくすることは一見ばからしいてとのよう であるが，てれを少なくするように努めないと，せっ かくよいものも使用した結果はかえって䒼いというこ とになりかねない.
一つの新幹線用台車というものができたということ は，高級な技術者の能力もさるととながら，わが国の 末端に至るまでその技術がかなり優秀であるととを示 しているものであろう。 と同時に，今後ての期待を裹 切らないようお互いに，学問的にも実際面においても 努力したいものである.

(昭和 41 年 5 月 17 日 日本材料学会第 15 期総会講演にて講寅)

\section{参 考 文 献}

39）中村宏, 小西正一, 甘粕達雄ほ加, 鉄研速報, No. 58-32 (1958).

40）中村宏，田村伸二，小西正一，東海道新幹線に関 する研究 (第 3 冊), p. 201 (1962).

41) 中村宏, 田村伸二, 渡辺喜一, 材料試験, 10, 972 (1961).

42) 中村宏, 田中真一, 日本機械学会論文集, 32, No. 244, 1755 (1966).

43）中村宏, 広瀬正吉, 鉄道業務研究資料, 11, No. 8，8（1954）；住友金属部内報告

44）中村宏, 小西正一, 材料試験, 7, 188 (1958).

45）中村宏, 上田四郎, 中井龍夫, 機械学会誌, 61, 1367 (1958).

46) 中村宏, 中村和雄, 小野修一, 日本機械学会講演 会前刷 (1953).

47）三木忠直，中村宏，国際溶接学会（1954）.

48) 中村宏, 上田四郎, 甘粕達雄, 日本機械学会論文 集, 25, No. 147, 804 (1958).

49）藤田公明, 東海道新幹線に関する研究 (第 5 冊), p. 304 (1964).

50）藤田公明, 中村宏, 金属材料， 6, No. 7，101 (1966). 